\title{
Right to Dream! A Postcolonial Reading of Tameez, a Dreamer in Elias' Khowabnama as a Subaltern Victim of Capitalism
}

\author{
Md. Mahfuj Hassan Bhuiyan
}

Lecturer, Department of English, Uttara University, Uttara, Dhaka, Bangladesh

Email: mahfujhassan@ymail.com

\begin{abstract}
The book Khowabmana by Akhtaruzzaman Elias reflects the 'hegemony' of the bourgeoisie class: in the beginning of the novel as Jamindars and later on as emerging capitalists. The hegemony puts the planters like Tameez under a 'false consciousness' that leads him to extreme misery. Thus, he becomes the victim of capitalism and a voiceless subaltern. This study attempts to identify 'capitalism' as the catalyst of class antagonism, side by side, it also discovers 'capitalism' as a 'fake dream' which makes tenant planters like Tameez a subaltern. This study is guided by a number of theoretical frameworks, for instance, Marxist idea of 'capitalism' and 'class antagonism' along with Engle's concept of 'false consciousness'. Gramcsi's concept of 'hegemony' (1999) is used to identify the concealed politics of bourgeois class to make the working class people submissive and voiceless. The 'New-Capitalist' class or the former Jamindars employ ISA, i.e. Ideological State Apparatus, and in some cases RSA, Repressive State Apparatus (introduced) by Louis Althusser (1970), to keep the marginalized people dominated. Thus, the dream that has been laid by 'capitalism' makes one, i.e. Tameez, a 'subaltern'; who does not have a voice to rise against suppression as well as a voice to establish his rights. Tameez's becoming of a subaltern and a voice less character is the ultimate consequence of 'capitalism'; this underlying politics of 'capitalism' is identified by incorporating Spivak's idea of "Can the Subaltern Speak?" (1988). Moreover, the working class people are always put under a 'false consciousness': capitalism is the force that will change their lot and will bring the light of happiness. However, instead of being the Subject, they -- to be specific the marginalized people like Tameez -- become the 'subject' of their subjugation, i.e. capitalism; which makes people like him/them a 'subaltern' and a dreamer whose dream(s) never get the touch of reality, although their life past centering their dream(s).
\end{abstract}

Keywords-Postcolonial, Subaltern, Capitalism, Hegemony and Nationalism.

\section{INTRODUCTION}

Akhtaruzzaman Elias' Khowabnama, The Dream Book, talks about the dream that working class planter's nurture in their mind, i.e. one day they will become an independent farmer with their own cultivable land and cattle. However, the suppression and the dream of being a solitude planter lead the working class people like Tameez in unconditional misery. It is, therefore, important to identify the hidden drive, i.e. Capitalism as the manipulating essence which makes tenant farmer like Tameez a 'subaltern'.

The working class people are always put under a 'false consciousness': capitalism is the force that will change their lot and will bring the light of happiness. However, instead of being the Subject they become the 'subject' of capitalism; which makes people like Tameez a 'subaltern' through remembering Spivak's argument "can the subaltern speak?"
Tameez is compelled to migrate to town to work in the house of a leader of the Muslim league. He had to migrate there because of the police case is given by Kalam Majhi but we see that he has a nostalgic will to go back to his village to stay with his newly married wife and daughter and we see a very significant nostalgic dream of land and to be a full-time farmer (a dream of a cultivable land and a pair of cows). He will work in his land and his wife Fulbanu will help him in farming and together they harvest lots of crops and there will no one to demand his percent of the crops. He actually started dreaming this after his return from Joipurhat where the Tevaga movement was going on and he had a great influence on the movement throughout the novel. For that reason, we see that when he was forcedly migrated from Bogra to Dhaka, he cannot control him dreaming and cannot stop him from joining Tevaga. He left the train and catch another to meet with is dream Tevaga. 


\section{OBJECTIVES}

This study attempts to discover if Tameez is the representation of the voiceless people of working-class society, in other words, to discover, if Tameez is a subaltern or not. Side by side it also inquires the concealed 'hegemony' of capitalism. This research investigates the 'false-consciousness' that is put in front of the marginalized people like Tameez and excavates Tameez as a subaltern victim of capitalism in addition with unmasking the politics of capitalism: the dream that makes people like Tameez submissive and suppressed.

\section{METHODOLOGY}

It is a qualitative research in nature which examines 'hegemony' of the bourgeoisie class of the novel as Jamindars and later on as emerging capitalists, which incorporates library research. Data is collected from printed books and journals as well as online resources. Printed books and journals apart, being an analytical research, this study employs the idea of class antagonism and 'false consciousness' discussed by Karl Marx along with his idea of the emergence of capitalism, Gramsci's concept of 'hegemony', and Spivak's idea of being 'subaltern' from her essay "Can the Subaltern Speak". Along with the Marxist idea of capitalism, it includes the theory of ISA (Ideological State Apparatus) and RSA (Repressive State Apparatus) by Althusser.

\section{RESULTS AND DISCUSSION}

Aktaruzzam Elias's Khoabnama is a socio-political novel where he connects the history from the colonial period to the partition of the Indian subcontinent. The nationalist movement first occurs against the colonialists. This movement gives birth to the dream of a national community; similar to Benedict Anderson's Imagined Community (Ashcroft et. al 123). People started to think about a continent without the oppression of the British, hence it leads to the dream of being independent according to religion (i.e. India for Hindus and Pakistan for Muslims). Mediate these dreams there go on some smaller dreams such as Tevaga dream- of the farmers, the dream of being free from the feudal lords- of the subalterns. Later on, this novel shows that how these nationalists become the 'dictator' of the country and the way to the partition of the Indian subcontinent and how Feudalism transforms into Neo-capitalism through Imperial Hegemony, power practice of the 'superior', Diasporal and making docile2 subalterns like Tamiz, Fuljaan, and Keramot Ali. These subalterns are put under a false consciousness where they are not given the ability to fulfill their dreams other than dreaming only. The Title of the Novel Khoabnama- 'The
Dream Book' exposes the idea of dreaming politics, which is inevitably accelerated by the nationalist movement, which is injected and is controlled in such a way that consequences the neo-colonial condition of the country. Here we can see that how the righteous idea of nationalism gives birth to the oppression of the neo-capitalists. According to Franz Fanon nationalism is the sense that "a national culture is the whole body of efforts made by a people in the sphere of thought to describe, justify and praise the action through which that people have created itself and keeps itself in existence" (Ashcroft et. al 119).

In Elias's Khoabnaama we see the formation of the nationalist movement which is nothing but an 'empty shell' and is making the local power holders the neocapitalist, i.e. Sharafot Mandal and Kalam Majhi, through taking the mythical spirit of Munshi (one of the rebels who rebelled against the British Army). Elias shows the historical timeline of our nationalistic spirit. To portray it he refers to the very first waragainst the British for independence which is known as the Fakir-Sannyasi Rebellion. In this war, general people participated vividly under the command of FaqirMajnu Shah. The war took place in 1787 where the great leader Fakir Majnu Shah died. Shah's spirit and revolutionary mind work as a shadow inside the novel under the name of Bayatullah Munshi (a co-operator of Fakir Majnu Shah). Elias with his mighty pen inserts Shah's revolutionary spirit as a very powerful mythical character named Munshi. Each and every one of from Nijgirir Danga believes that he lives on the Pakur tree and surveillance the area especially Katlahar Bil. The spirit of Fakir-Sannyasi Rebellion might seem invisible but it is the dominant theme of the novel. We see that another revolution Tevaga powered by the farmers come to that area where Fakir-Sannyasi Rebellion took place. At one time the ancestors of the people of Nijgirir Danga fought against British tyranny and oppression now they are fighting against the landlords for the same reason. As ill luck would have us that we fought against British Tyranny to imprison ourselves under the local landlords rather liberated ourselves. Tevaga is the spirit of the general people against oppression. The spirit of the movement is another dominant theme of the novel from starting till the end. Under the agglomeration of this spirit, the subaltern people started to dream about their own farming land and to dream about the salvation from the feudal lords. However, this local subjugated people's dreams indeed used as the weapon for the mainstream politicians' own benefit for getting the authority over the subjugated people. The idea of the secular nation, secular language and secular land of Muslim League and Congress Party gave birth to Riot and successfully ended up with the 
partition of Indian Subcontinent into two distinct countries-India and Pakistan in 1947. For this nationalistic movement, the dream of Tevaga vanished and remained as a dream to the subalterns like Tameez and Hormutullah.

In terms of the novel Khowabnama, the Muslim nationalism raised by Kader - the youngest son of Sharafat Mandal-a local landlord at Nijgirir Danga, is a leading local Muslim league leader. He started to raise consciousness about the rights of the 'colonized' people not to bring them the light of progression but to manipulate them against the local Hindus; later on which would add to greater movement of partition. He on behalf of his party showed that how they were constantly being subjugated and misjudged by the Hindu Jamindars and how separation can be the only solution to this oppression. This can be regarded as a clear reflection of 'hegemony' practiced by the ruling class. As the definition of hegemony says "Hegemony is the power of the ruling class to convince other classes that their interests are the interests of all, often not only through means of economic and political control but more subtly through the control of education and media."

Kader along with other Muslim League's leader convinced Muslim people by saying that unless or until they get rid out of the Hindu Jamindars and Hindu rulers they would not get the accurate freedom for what Muslim League is fighting.

Another masking of the idea of nationalism is the transition of Feudalism to 'Capitalism', is also vividly mirrored in the novel Khowabnama. Elias shows the transition from feudalism to capitalism through the characterization of the characters like Sharafat Mandal, Kalam Majhi, and Abdul Ajiz. Each one of them was once framer and in the latter part of the novel, they are viewed as the local landlords. In addition, gaining political and economic power they have become the centre of economy of that area which leads to neo-capitalism. They become the representative of general people. Apparently, it seems that out of their noble personality they are representing the 'proletariat' class of the area but inreality they are the benefit seeker. They gave the 'proxy' of the subalterns like Tamijer Baap and Tameezor Kulsum by representing them not 'representing' them through their 'portraiture'.

The idea of nationalism is raised by the Neo-capitalists, thus, it kills the people's spirit (Tevaga) to save their back. The new and successful nationalistic movement continuously losing its spirit and is being transformed into a bourgeois interest; soon we see the consequence of national conciseness which works as a within weapon to gather the marginalized people through hitting their national consciousness.

Elias clearly portrays how the idea of nationalism works as the catalyst to rise of Neo-capitalism. Sharafat Mandal and his two sons worked to raise national consciousness, and emerged as the representation of the 'neo-capitalist' of Nijgirir Danga. They grabbed lands from the farmers suppressing them under in debt. They have also taken over the local Hindu property and introduced brickfields in the rural area. This shows the power practice of the local leaders and the transition of them into neo-capitalists. This transition suggests Hegel's idea of 'material historicism'. This nationalistic atmosphere also leads to another negative impact of nationalism that is landlessness. The cause of 'Riot', 'Separation' and 'Migration' of both Hindus and Muslims all are caused by a powerful group of people's own interests. In the time of separation in 1947 , the Hindus who left the property and migrated to India, soon their property is grabbed by neo-capitalist who were the nationalist who used their political power to grab others property. Elias focuses on a smaller frame to show the transition-Katlahar Bil and the nearest area was his focus point. Here Tameez was an enforced migrates who once used to be a fisherman than a farmer and then become a fortune seeker in the town. He had to migrate there because of the police case is given by Kalam Majhi. We see that he has nostalgia to go back to his village to stay with his newly married wife and daughter. Yet, he nourishes the 'dream' of being an independent farmer which in reality nothing but an illusion thus remains as a subaltern in the society for whom neither no one speaks nor he!

\section{WHO ARE THE SUBALTERNS IN THE} 'TEXT'?

Tameez's Father is a subaltern. He sometimes represented by Kalam Majhi who uses him as a shield against Sharafat Mandal. When Tameezer Baap (Tameez's Father) is bitten by Sharafat Mandal, Kalam Majhi stood beside him: not to speak for him but to get Katlahar Bil. He always searches for issues to rise against Mandal to get Katlahar Bil.

Kulsum is another subaltern who is also the victim of Kalam Majhi who tried to rape her. Though he gave her shelter in his house but is for his own purpose. He invaded 'Tameezer Baper', i.e. Tameez's Father's land where he builds a mosque later.

Tameez is the big subaltern here where he is represented by anyone and everyone. KalamMajhi misrepresents him in some places to get his father's land. Kader and the leader of the Muslim League misrepresent him politically to get the support of Majhi Para. 


\section{DREAM THAT CONTINUES: TEVAGA}

Tameez is forcedly migrated to town to work in the house of the leader of Muslim league. He had to migrate there because of the police case is given by Kalam Majhi but we see that he has a nostalgic will to go back to his village to stay with his newly married wife and daughter and we see a very significant nostalgic dream of land and to be a fulltime farmer (a dream of lands and cows). He will work in his land and his wife Fulbanu will help him in farming and together they harvest lots of crops and there will no one to demand his percent of the crops. He actually started dreaming this after his return from Jaipur hat where the Tevaga movement was going on and he has a great influence on the movement throughout the novel. For that reason, we see that when he was forcedly migrated from Bogra to Dhaka, he cannot control him dreaming and cannot stop him from joining Tevaga. He left the train and catches another to meet the dream: Tevaga.

\section{HEGEMONY AND NATIONALISM: JUXTAPOSED WEAPON TO DOMINATE AND TO MAKE PEOPLE SUBMISSIVE}

Kader and Muslim League's leader convincing Muslim people by saying that unless they get rid of Hindu landlords and ruler they will not get freedom and Muslim league is working for Muslim to be separated from Hindu and for their betterment they should support Muslim league. Elias uses a big frame of history to show the timeline of our nationalistic spirit. To portray our nationalistic spirit he refers to a very first war for independence against British .this war or revolution was the revolution by the general people for them. That war took place in 1787 where the great leader Majnu Shah died. Shah's spirit and revolutionary mind work as a shadow inside the novel for this reason we come to know about him as a very powerful mythical character. Each and every one believes that he lives on the Pakur tree and rule the area especially Katlahar Bil (a pond is locally called Bil). I see that another revolution Tevaga come to that area where Fakir Revolution took place also by general people; once their ancestor fought against British tyranny and oppression they fought against the landlords for the same reason. Tevaga is the spirit of the general people against oppression. The spirit of the movement is the dominant theme of the novel from starting till the end. Though again the spirit and the revolution of the general people lose to another nationalist movement raised by mainstream politicians who are actually bourgeois that was religious nationalism raised by Muslim League and Congress. It gave birth to bloody riot and successfully ends in 1947 by separated in two countries India and Pakistan.

Muslim nationalism raised by Kader, son of Sharafat Mandal, is a leading local Muslim League leader, started to talk about the rights of general people and for his party to raise a nationalistic consciousness against Hindu and to attain the support for his party. He argues about how they are oppressed and misjudged by Hindu landlords and how the only separation can stop the oppression. He also put the dream in front of the general people to get the absolute freedom to live their life as per the 'created' dream.

\section{THE NEW CAPITALISTS AND THE 'OLD' DREAMER(S)}

Elias clearly portrays the manipulation of use of the ideanationalism and the rise of Neo-capitalism. Sharafat Mandal and his two sons: who works to raise national consciousness become neo-capitalists. They grab the land of ordinary people and establish brickfields. They grab Hindu property in the town as well. They then become the person who controls other: people like Tameez, Keramot Ali is another example of this 'historical' transition. He changes his color like the chameleon from nationalist to petit bourgeois: who once used to be a devoted person for general people's right becomes an oppressor; who writes songs for Tevaga. Kalam Majhi another neo-capitalist stand against his genus and cheat with the people by grabbing their land and plot police case against Tameez: the person who is the victim of all time. He uses muscle power to grab Mukundo Shaha's shop by killing Boikhuntha.

\section{CONCLUSION AND RECOMMENDATION}

Tameez is the representation of the marginalized people of the society who is suppressed under the capitalist hegemony; whose dream never gets the touch of reality rather brings him extreme misery in life. At first, he became the slave of the hierarchy through their 'Tevaga' ideology and then he is repressed by Kalam Majhi to be dominated. Thus, he remains as a voiceless character; running after his dreams to save is back. And, it is the dream that will never come to end, rather, indulging 'the' dream itself. As for the shortage of research time, one of the major themes of the novel, i.e. representation of the female characters is not discussed.

\section{ACKNOWLEDGEMENTS}

It is my pleasure to acknowledge the extra-ordinary supervision, invaluable suggestions, and proper guidance of my respectable Associate Professor Mashrur Shahid Hossain whose criticism and advice have shaped the paper 
at every stage of writing. I express my humble gratitude to him. Without his kind cooperation and help this paper would never have been possible. Finally, gratitude is also due to my parents and my wife for their constant support and inspiration to accomplish the job.

\section{REFERENCES}

[1] Elias, Akhtaruzzaman. Khowabnama. Dhaka, 1995. Print Perfect, T. J., \& Schwartz, B. L. (Eds.) (2002).

[2] "Ideology and Ideological State Apparatuses (Notes towards an Investigation)" Ideology and Ideological State Apparatuses by Louis Althusser 1969-70. Web. 10 July 2015.

<https://www.marxists.org/reference/archive/althusser/1970/ ideology.htm>.

[3] "Karl Marx: Theory of Class Consciousness and False Consciousness - Video \& Lesson Transcript | Study.com" Study.com. Web. 10 July 2015.

[4] "Marxist Media Theory." Marxist Media Theory. Web. 10 July 2015.

<http://www.aber.ac.uk/media/Documents/marxism/marxis m10.html>.

[5] "Repressive State Apparatus - Oxford Reference." Repressive State Apparatus - Oxford Reference. Web. 10 July 2015.

[6] Spivak, Gayatri Chakravorty. Can the Subaltern Speak? Basingstoke: Macmillan, 1988. Print.

[7] Tyson, Lois. "Marxist Criticism" Critical Theory Today. Second ed. New York, 2006. Print. 